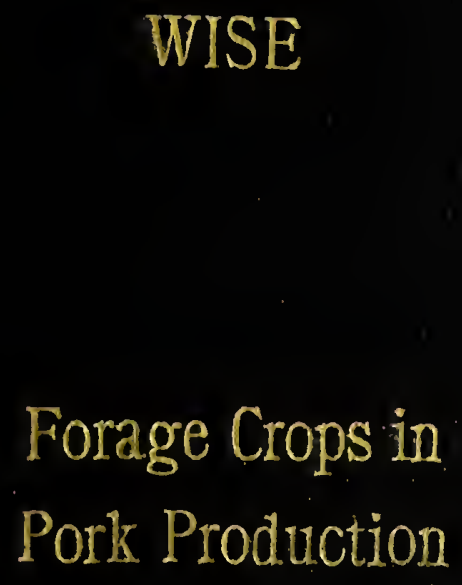

Agriculture

B. S.

. 1904

OSIVERSITY

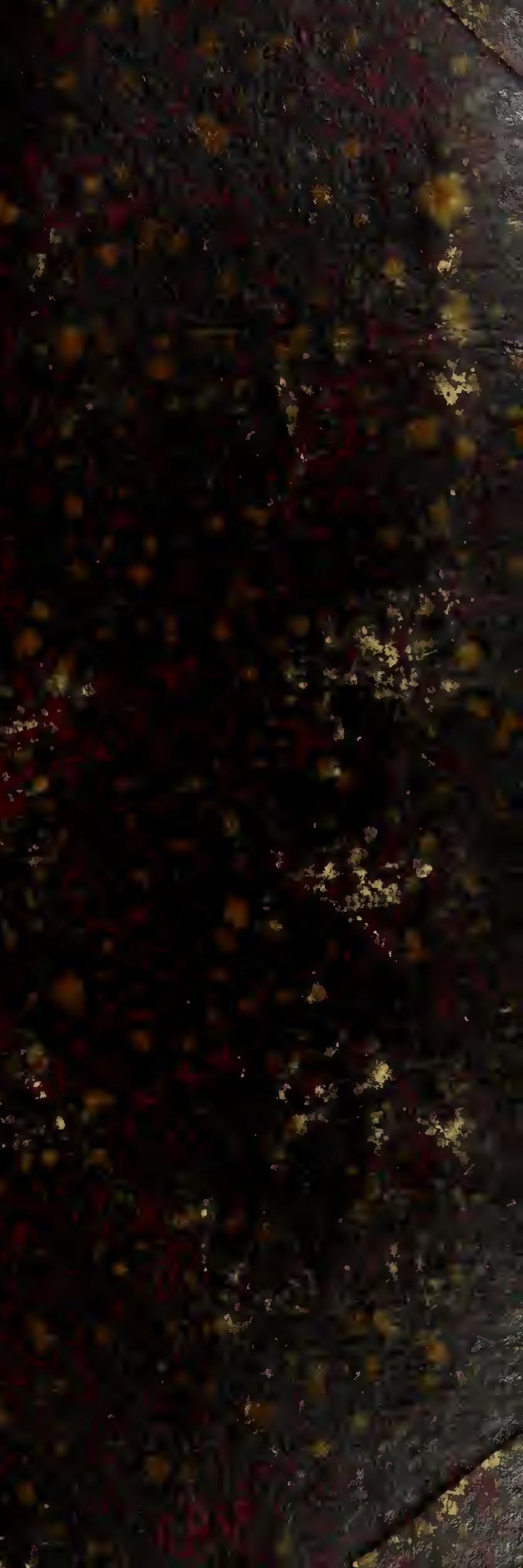


UNIVERSITY OF ILLINOIS

LIBRARY

BOOK CLASS
$1904 W 75$ 




\title{
THE PLACE OF FORAGE CROPS IN PORK PRODUCTION
}

BY

\author{
LEWIS W. W'ISE
}

\section{THESIS}

FOR THE

DEGREE OF BACHELOR OF SCIENCE

IN THE

COLLEGE OF AGRICULTURE

UNIVERSITY OF ILLINOIS 


\section{Digitized by the Internet Archive in 2013}

http://archive.org/details/placeofforagecro00wise 
$\frac{1904}{W 75}$

UNIVERSITY OF ILLINOIS

thay 24 .no

THIS IN TO OMTHEY TIIAT TIIE THESIS PREPARED UNDER MY SIPERVISION BY

Lunis It. Tfwe

1) Place of Zerags Onopo ui Pork Preduction.

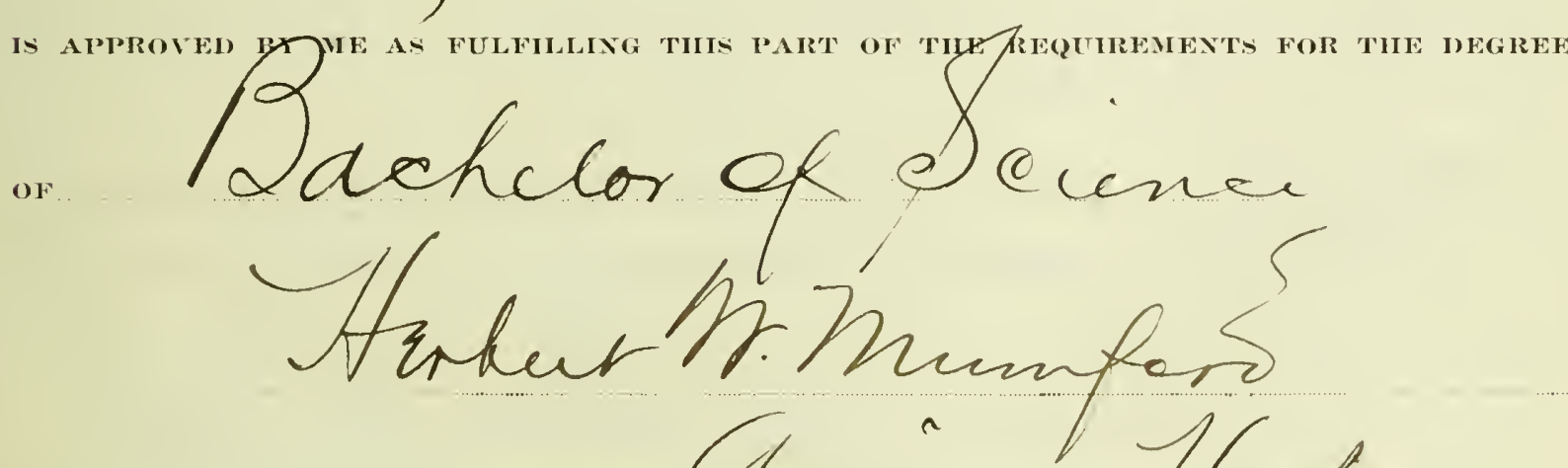

or Animal Itustiondry

6oths 



\section{THI PLACE OF FORAGE CFOPS IN PORE PRODUCTION.}

\section{Introduction.}

The custom in many sections of the corn belt is to keep hogs in a ary lot and cive them a ration consisting almost entirely of coln through the whole of the fattening period. By the fattenine perioa is meant the time during which hoss are fea and preparec for market. Corn alone for the last few weeks or feeding is the best reed that can be used, but with young hogs whore both growth and fat are desired it, is better to feed something with the comn. By some farmers the corn is supplemented with shorts.

In oraer to gain some practical information in feeding the forazo crops clover and rape as well as shorts with corn a test was outlined and carried on as given in the following pages.

The object of the experinent was to compare clover, rape and shorts when used as a supplement to corn as a feed for fattenine homs. This is not an entirely new subject but comparatively little data has been collecteà according to this plan. No data at all has been collected from a test of this nature in our state. In the latter pages of this thesis will be founa some results of feeding tests conaructec at risconsin, which were with younger pigs and more applicable to growing pigs. A record of the cost as tabulatec in table 9 will show whether or not it will pay to pasture hoge on a forage cro, wille they are being fattened. 



\section{Plans of the Experiment.}

Pigs.-. To mak the experiment mean as much as possible it ".as necessar: to bu; pigs that had been similarly breci and fec. Sixteen jEs reighing about 155 pounās Each and as nearly uniform as possible were securec for this experiment. The pigs were about eight months old when the experiment began. They were grade Poland-Chinas of a good trpe; none of them were of the longlean type, but a few were somewhat chunky. The had previouslinfed on a corn ration anc kept in a dry lot hence had never grown in size as they chould have done. They were lackine in thriftiness.

Enuipments.-- Mhe troughs used for the various lots were made of ten inch boarảs six feet long. These boarás mere noilec together in the common way thus making a $\mathrm{v}$ shared trough.

To beds "rere used as it was not thoucht necesscri auring tre suminer months.

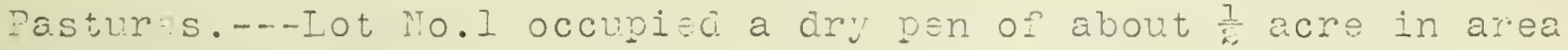
trees

with shaden on the east side of it which furnished protection from the hot sun.

Lot Ho.2 occupiec a similar area. xcept that these pigs were protectea from the hot sun bu trees on the west sice.

Lot "o.3 occupieo a small pasture of about an acre in area anỏ the piess w protected from the hot sun by a roof bein built out in the pasture. This area furnisheo more forage than the hoss constmed.

Lot No. 4 occupiea a clover pasture of about an acre in area. This lot had similar protection from the hot sun as did lot No.3.

Feed and Feeding.--An accurate account of all the coin and shorts fed was kept. Since the pims on the clover ana rape lots 

grazed at "ill no accurate account could be kept of the forage they at.. This however was oeternined on a basis of cry matter per given amount of gain made. The äry matter consumea per 100 pouna Gain in the corn fed lot, which recievea nothing but corn and water, ":as detarmined; ther the cains made by the clover and rape fod lots "was ove: and above that made by the corn fed lot was consicereo to be due to the clover and rape. The amount of clover and rape consumea lias then determined in pounds of dr. matter, and from this the amount in pounds of clover and rape eaten. While this is not absoIutely correct it will do by way of comparison. "e all know that it takes less ary matter per 1 1b. fain where a supplemental feed Iike clover or rape is adäed to a ration of com than wheie corn alone is fed. This then has the tencency to minimize the eIfect of clover and the rape.

The corn was fed to each lot twice a day one feeci about six o'clock in the morning and the othen resa after six o'clock in the evenins. Wate. was given to each lot so that the had readi scess to it at all times.

The shorts were soaked several hours before feeding and eiven at the same time the corn was fed.

The clover was fenced from a fiela which had been pasturea by horses and cattle until JuIy 8th. It was in a very thrifty conäition at this time and furnished an abundance of good foraso airing the whole of the experiment.

The rape was som at the rate of six pounds per acre on April 15t:. The variet. used was the Iwarf Essex. Oring to cool damp -..eatier followed by a dry spell it frew very slowiy at first but by JuIy Sth. it was in sooc condition for pasture and fumished nore 

forage than was consumed by the pics. The rape was more plentiful at the close of the test than it was at the beginning.

After the four days of preliminary feeding the pigs were weighed out in four lots, each lot containing four piss. The lots were :ieighed out on lionday morning July 8th, and weiched each following Nonday momine till close of experiment Aug. Ioth.

The feedin proper extended over a perioc of seven weeks during which time the data siven in the following tables was collected.

The experiment begun July 8th, and ended Avecust 19th. All the Data necessary for a comparison of gains made by the different lots are tabvlated, topether with tables showing the financial results of the experiment.

Before the experiment proper beman all the piss were put into one pen and fed lightly on corn and water for four days. After this period of preliminary feeding, which was for the purpose of bringing the pigs to a uniform basis for starting, they were separated into four lots as outlined above. The data collected is as folloms. 

Data.

Table ilumber I

Lot 1

corn and Water.

\begin{tabular}{|c|c|c|c|c|c|c|}
\hline $\begin{array}{l}\text { Time } \\
\text { of } \\
\text { rits. } \\
\end{array}$ & $\begin{array}{l}\text { Av.Tt } \\
\text { of } \\
\text { Hoge IDS } \\
\end{array}$ & $\begin{array}{l}\text { Total } \\
\text { Tts. } \\
\text { los. }\end{array}$ & $\begin{array}{c}\text { Lbs.of } \\
\text { comn } \\
\text { per da. }\end{array}$ & $\begin{array}{l}\text { Laily f'eed } \\
\text { in per cent } \\
\text { of live rt. }\end{array}$ & $\begin{array}{c}\text { Av.dail } \\
\text { gain } \\
\text { Ibs. }\end{array}$ & $\begin{array}{l}\text { Food for } \\
100 \text { Lbs. } \\
\text { gain. }\end{array}$ \\
\hline JUIY 8 & 160.40 & 055 & 23.20 & 3.54 & & \\
\hline " 15 & 170.75 & 683 & 23.20 & 3.38 & 1.00 & 580 \\
\hline " 22 & 178.25 & 717 & 27.84 & 3.38 & 1.25 & 463 \\
\hline$" 20$ & 186.25 & 747 & 27.84 & 3.72 & 1.07 & 019 \\
\hline Aug. 5 & 195.75 & 783 & 27.84 & 3.55 & 1.28 & 541 \\
\hline " 12 & 200.75 & 803 & 27.84 & 3.46 & .74 & 914 \\
\hline " 19 & 207.50 & 820 & 27.81 & 3.55 & 1.00 & 696 \\
\hline Total & 186.35 & 745 & 27.84 & 3.55 & 1.05 & 637 \\
\hline
\end{tabular}


- 
Table number I shows average weight and total weight of hợs, the amount of corn eaten aaily, the daily feed in per cent live "reight, average daily gains and feed for 100 pounds gain. The averago daily gain of this lot was 1.05 pounds. The averace daily feed in per cent of live weight was 3.55 . That is each 100 pounds of live hog required 3.5 pounds of corn for his daily ration. It took 6. 3: pounds of com for each pound of gain or 637 Ibs. per 100 pounds gain. Althoum no large cains were made there was nothing out of the ordinary noticed in this lot. The pies were started on 5.8 pouncis of feed per day which was increased until they were getting 3.96 pounds per day at which amount they were kept. It will be noticed that the largest gains were made at the end of the second week when the pigs were getting the largest amount of feed. At this point their daily feed was 3.88 per cent of their live weight. As the piss crew in weight the daily reed which remained stationary grew pro ortionately less anc a proportionately greater amount of it ras consumed as the food of support. 

Table inumber 2

Lot 2

Corn and shorts.

\begin{tabular}{|c|c|c|c|c|c|c|c|}
\hline $\begin{array}{l}\overline{\text { Time }} \\
\text { of } \\
\text { Tits. } \\
\end{array}$ & $\begin{array}{l}\text { Av. Tt . } \\
\text { of } \\
\text { Hogs.Iu }\end{array}$ & $\begin{array}{l}\text { Total } \\
\text { Tyts. } \\
\text { los. }\end{array}$ & $\begin{array}{c}\text { Lbs.of } \\
\text { com } \\
\text { per da. }\end{array}$ & $\begin{array}{l}\text { Ibs.of } \\
\text { shorts } \\
\text { per da. }\end{array}$ & $\begin{array}{l}\text { Daily feed } \\
\text { in per cent } \\
\text { of live mt. }\end{array}$ & $\begin{array}{c}\text { Av.daily } \\
\text { sain } \\
\text { Ios. } \\
\end{array}$ & $\begin{array}{l}\text { Feed for } \\
100 \text { Ibs. } \\
\text { gain. }\end{array}$ \\
\hline JUIy $\varepsilon$ & 157.00 & 328 & 13.92 & 6.48 & 2.1 & & \\
\hline " 15 & 165.00 & 560 & 23.20 & 0.48 & 4.4 & 1.14 & 538 \\
\hline$" 2 \varepsilon$ & 176.25 & 705 & 23.20 & 6.48 & 4.2 & 1.60 & 360 \\
\hline$" 20$ & 182.50 & 730 & 22.20 & 0.48 & 4.0 & .80 & 649 \\
\hline Auñ. & 192.50 & 770 & 23.20 & 6.48 & 3.8 & 1.42 & 405 \\
\hline "I & 200.00 & 800 & 23.20 & 0.48 & 3.7 & 1.02 & 540 \\
\hline$" 1 c$ & 206.25 & 825 & 23.20 & 0.48 & 3.4 & & 045 \\
\hline$\overline{\mathrm{Avg} .}$ & 182.77 & 731 & 22.01 & 3.48 & 3.6 & 1.1 & 528 \\
\hline
\end{tabular}





\section{$-8-$}

The pigs of this lot made larger gains than the ones in lot number 1. They made an average of 1.15 pounds daily, but this extra gain was not large enough to pay for the shorts consumed. The quality however of the pigs was better in this lot than in the com fea lot, they had a smoother coat of hair and showed a better finish in every way. The difference in quality would have been at least 5 \& per 100 pounas which with the extra gain lessened the cost of the pork produced by the lot by . The shorts fed to this Iot cost 55 . The extra price recieved for this lot was not sufficient to pay for the shorts. One pound of pork in the corn and shorts fod lot cost 002 while in the corn fed lot it cost only \$.050. One interesting feature about this lot was their behavior when the shorts were poured in their trough. They would leave the com and immeciately hasten to the shorts. This shored that the were getting in the shorts some substance that was not present to in the corn

any great extent, and was much desired by the system. This seems

to indicate that a variety of feed is relished most even during the fattening perioa.

The manure of this lot was more valvable than of the corn fed lot on account of its higher nitrogen content.

Thile shorts is not always best to finish hogs on for the market, it is true that it is worth much more for groming hoss. 



$$
-9-
$$

Table itumber 3

$$
\text { Lot } 3
$$

\begin{tabular}{|c|c|c|c|c|c|c|c|}
\hline $\begin{array}{l}\text { Time } \\
\text { of } \\
\text { yts. }\end{array}$ & $\begin{array}{l}\text { Av.Wt. } \\
\text { of } \\
\text { Hogslbs }\end{array}$ & $\begin{array}{r}\text { Total } \\
\text { Wts. } \\
\text { lbs. }\end{array}$ & $\begin{array}{c}\text { Lbs.of } \\
\text { corn } \\
\text { per da. }\end{array}$ & $\begin{array}{c}\text { Lbs.of } \\
\text { rape } \\
\text { per da. }\end{array}$ & $\begin{array}{l}\text { Daily feed } \\
\text { in per cent } \\
\text { of live } T t .\end{array}$ & $\begin{array}{l}\text { Av.daily } \\
\text { gain. } \\
\text { Ibs. }\end{array}$ & $\begin{array}{l}\text { Feed for } \\
\text { loo Lbs. } \\
\text { gain. }\end{array}$ \\
\hline JuIy \& & 155.00 & 620 & 18.56 & 4.4 & 10. & & \\
\hline " 15 & 160.00 & 840 & 15.56 & 4.4 & 9.7 & .714 & 2180.0 \\
\hline$" 2 \hat{z}$ & 170.00 & 820 & 23.20 & 14 & 5.8 & 1.428 & 1170.0 \\
\hline$" 25$ & 177.75 & 710 & 23.20 & 44 & 9.4 & 1.071 & 1566.0 \\
\hline Aus. ¿ & 187.50 & 750 & 27.84 & 41 & 8.5 & 1.428 & 1257.0 \\
\hline " 12 & 195.75 & 783 & 27.84 & 44 & 0.1 & 1.104 & 1523.0 \\
\hline$" 15$. & 200.00 & 820 & 27.81 & 44 & 8.7 & 1.325 & 1359.0 \\
\hline$A v \widehat{A} \cdot$ & 178.85 & 714 & 23.83 & $\angle 4$ & 9.7 & 1.780 & $1295 . ?$ \\
\hline
\end{tabular}

Corn and Rape. 

This lot made good cains throushout the experiment, but the largest and most nearly even gains were made tomard the close of the test. The lighter gains at the beginning was probably due to the fact that the pigs were not accustomed to eating rape. At first they aid not seem to care for the rape at all, but the soon began eatine it as if they relished it. The rape vas more plentiful at last than when the experiment began, but at all times thero was an abunance of pastrre. The average daily gains of this lot was 1.19 Ibs. While the gains of this lot were ver little higher than for lot 2 , they vere more economical. The pigs consumed less corn ana the rape they ate was of much less value than the shorts consumed by lot 2. The pigs of this lot were in the best of physical condition through the whole of the experiment. The other lots showed no simns of sickness but the clover, rape and shorts lots ":ere in the best condition as was indicated by the loosness of thei: bowels. The rape lacks in protein content but the cains made vere very satisfactory and economical.

Table Number 4 Iot 4 ClOven.

\begin{tabular}{|c|c|c|c|c|c|c|c|}
\hline $\begin{array}{l}\text { ime } \\
\text { of } \\
\text { ts. }\end{array}$ & $\begin{array}{c}\text { AV I . } \\
\text { IDE. }\end{array}$ & $\begin{array}{r}\text { Total } \\
\text { Lbs. }\end{array}$ & $\begin{array}{l}\mathrm{Lbs} \cdot 0 \mathrm{f} \\
\operatorname{corn} \\
\text { per da. }\end{array}$ & $\begin{array}{l}\text { Lbs.or } \\
\text { clover } \\
\text { por da. }\end{array}$ & $\begin{array}{l}\text { Total feed } \\
\text { in pon cent } \\
\text { of live vt. }\end{array}$ & $\begin{array}{c}\text { Av.dail: } \\
\text { gain } \\
\text { Ibs. }\end{array}$ & $\begin{array}{l}\text { Feed for } \\
\text { loo Lbs. } \\
\text { cain. }\end{array}$ \\
\hline JUב: $\varepsilon$ & 138. & 72 & $16.13 \mathrm{~m}$ & 37.4 & 7.9 & & \\
\hline " 15 & 180. & 720 & 16.10 & 37.4 & 7.8 & 1.71 & 781 \\
\hline " 22 & 191.25 & 735 & 19.20 & 37.1 & 7.4 & 1.60 & 880 \\
\hline$" 29$ & 202.00 & 808 & 27.84 & 37.4 & 8.07 & 1.53 & 1068 \\
\hline AUC. 5 & 210.75 & 843 & 27.84 & 37.4 & 7.7 & 1.25 & 1313 \\
\hline " 12 & 217.75 & 871 & 27.84 & 37.4 & 7.5 & 1.00 & 1641 \\
\hline $117=$ & 227.00 & 908 & 27.94 & 27.1 & 7.1 & 1.32 & 1267 \\
\hline Av尺्ู. & 199.25 & $?$ & 23.26 & 37.4 & 7.28 & 1.40 & 11.55 \\
\hline
\end{tabular}



The piss of this lot made yood cains throughout the rhole of the experiment. It can be seen from the table that the best gains were made at the berinning of the test. This was probably due to the conaition of the clover at this time, which was ir full bloon auring the period of best gains. During this period the pigs would go along and nip off the clover heads as if there was something especially relishing in them. The clover was not so succulent tomara the close of the experiment, but an abunaance of good pasture was furnishea at all tines. This lot made better cains than the preceeding one. This is what one would expect because clover is richer in protein than is rape therefore will make a better ration when red with corn which is higily carbonaceous.

\section{Table Number 5}

Table showing average composition

or the reeding sturfs used, percentagely.

\begin{tabular}{l|r|r|c|c|c|c|c}
\hline \hline Feec. & Iry mat. & Prot. & Ash. & $\begin{array}{c}\text { Crude } \\
\text { Fiber }\end{array}$ & $\begin{array}{c}\text { Nit.rree } \\
\text { Fxtract }\end{array}$ & $\begin{array}{c}\text { Ether } \\
\text { Extract }\end{array}$ & $\begin{array}{c}\text { rutritive } \\
\text { Fatio. }\end{array}$ \\
\hline Corn & 89.4 & 10.3 & 1.5 & 2.2 & 76.4 & 5. & 1.9 .7 \\
Shorts & 82.2 & 14.9 & 4.6 & 7.4 & 56.8 & 4.5 & $1: 5$ \\
Fape & 15.5 & 2.3 & 2. & 2.6 & 8.4 & .5 & $1: 5.3$ \\
Clover & 29.2 & 4.4 & 2.1 & 8.1 & 13.5 & 1.1 & 1.5 .5 \\
\hline \hline
\end{tabular}





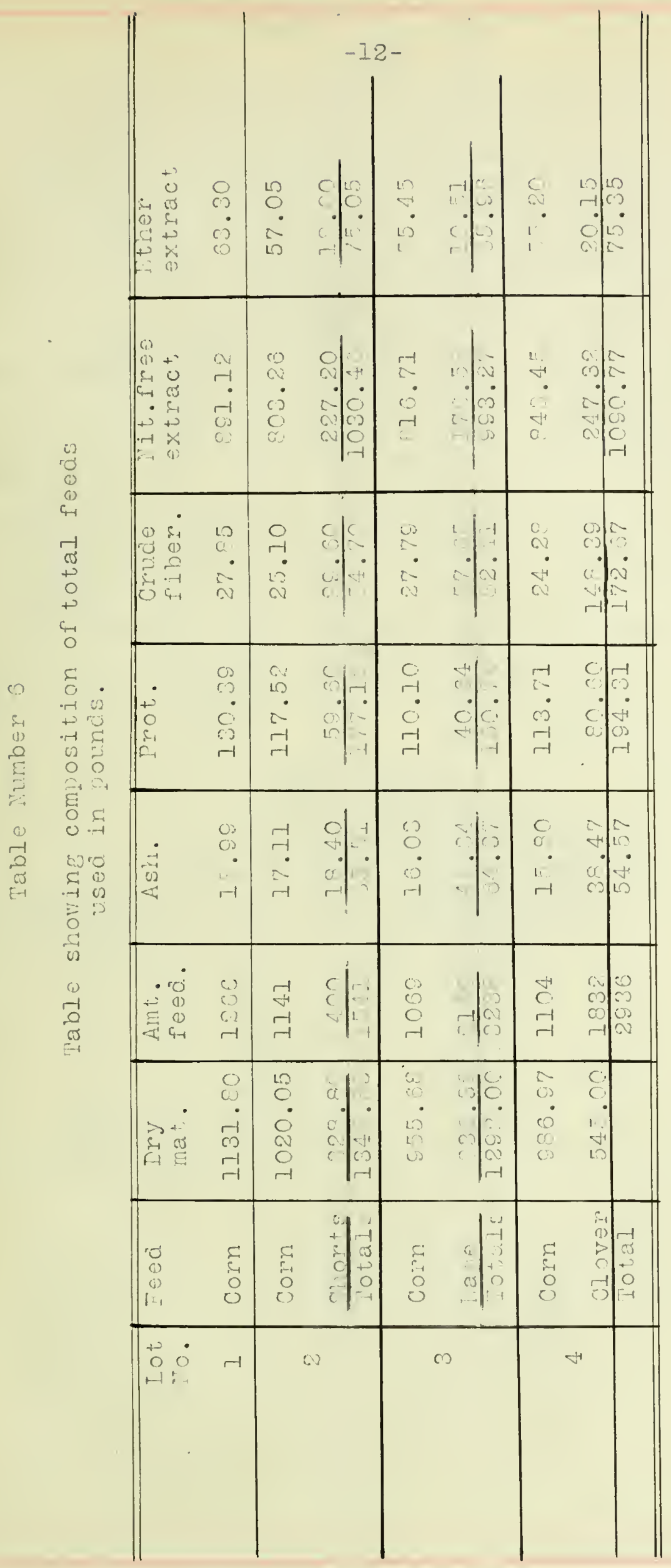



Table number 5 shows the average compositior of the feeding stuffs usec in the experiment. From these compositions table number. o has been computeci and it shows the total composition in pounds.

The amount of clover and rape was calculateo from the dry matter requirea to make 100 Ibs. cain in the corn feo lot. Iach 100 lbs. gain ::as calculated to require the same amount of dry matter as was required in the corn and water fed lot. The amount of corn fed in each case was known. Then tho total orj matter in terms of corn was computec and the difference between the dr: matter of the corn fed and the total dry matter is the dry matter in tems of clover or rape as the case may be. "hen the ary matter has been obtained the amount of clover and rape was calculated from that.

Table Number 7

Table showin.. digestible nutrients in feeding stuffs of the experiment, percentagely.

\begin{tabular}{l|c|c|c|c|c}
\hline \hline Feed & Dry má. & Prot. & Carbohycirates & Ether extract & \\
\hline Corn & 91. & 70.0 & 66.7 & 86.0 & 82.2 \\
Shorts & 88.2 & $9 . .6$ & 77. & 40.6 \\
Fape & 15.5 & 65.2 & 73.6 & 63.7 & \\
Clover & 28.2 & 65.8 & 68.5 & \\
\hline
\end{tabular}





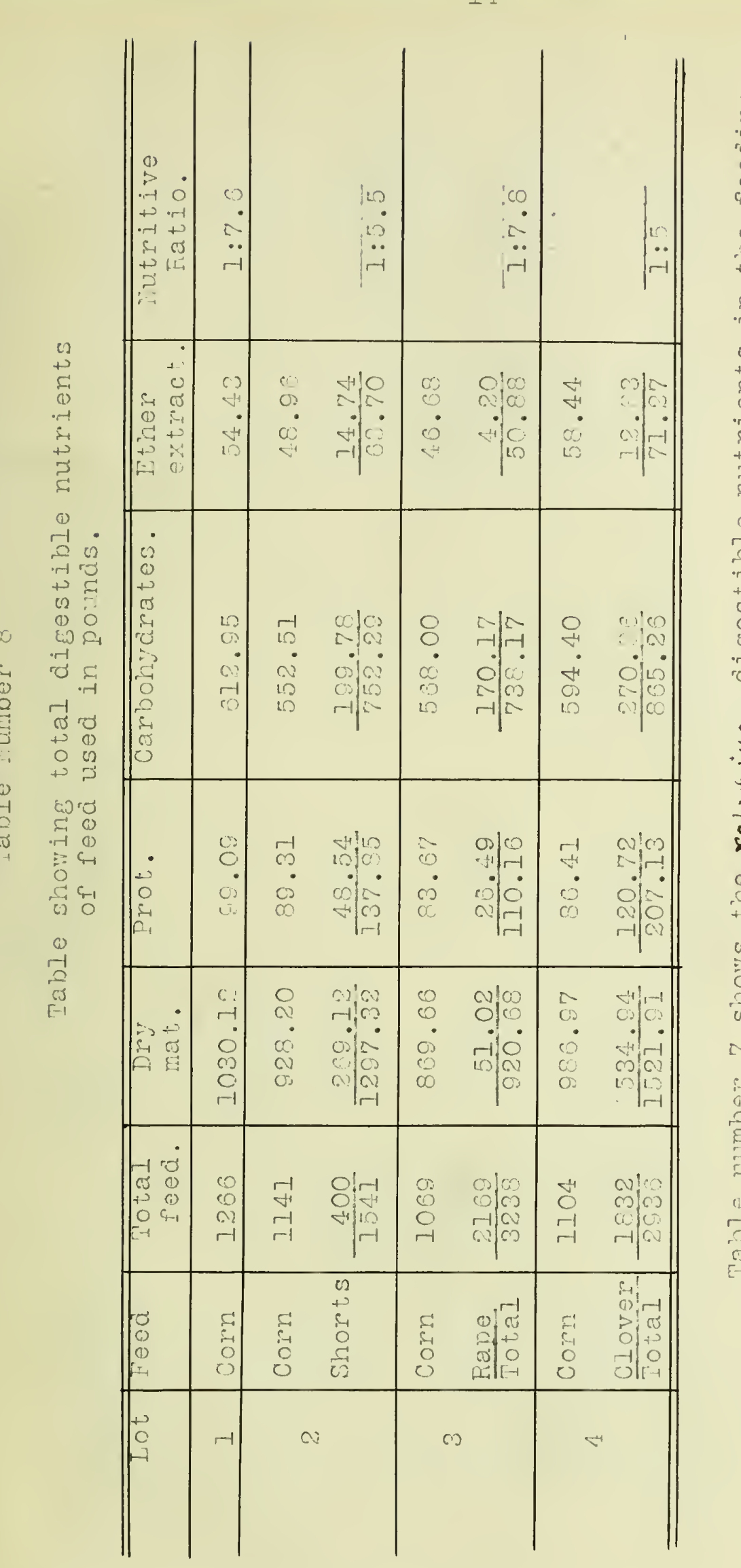





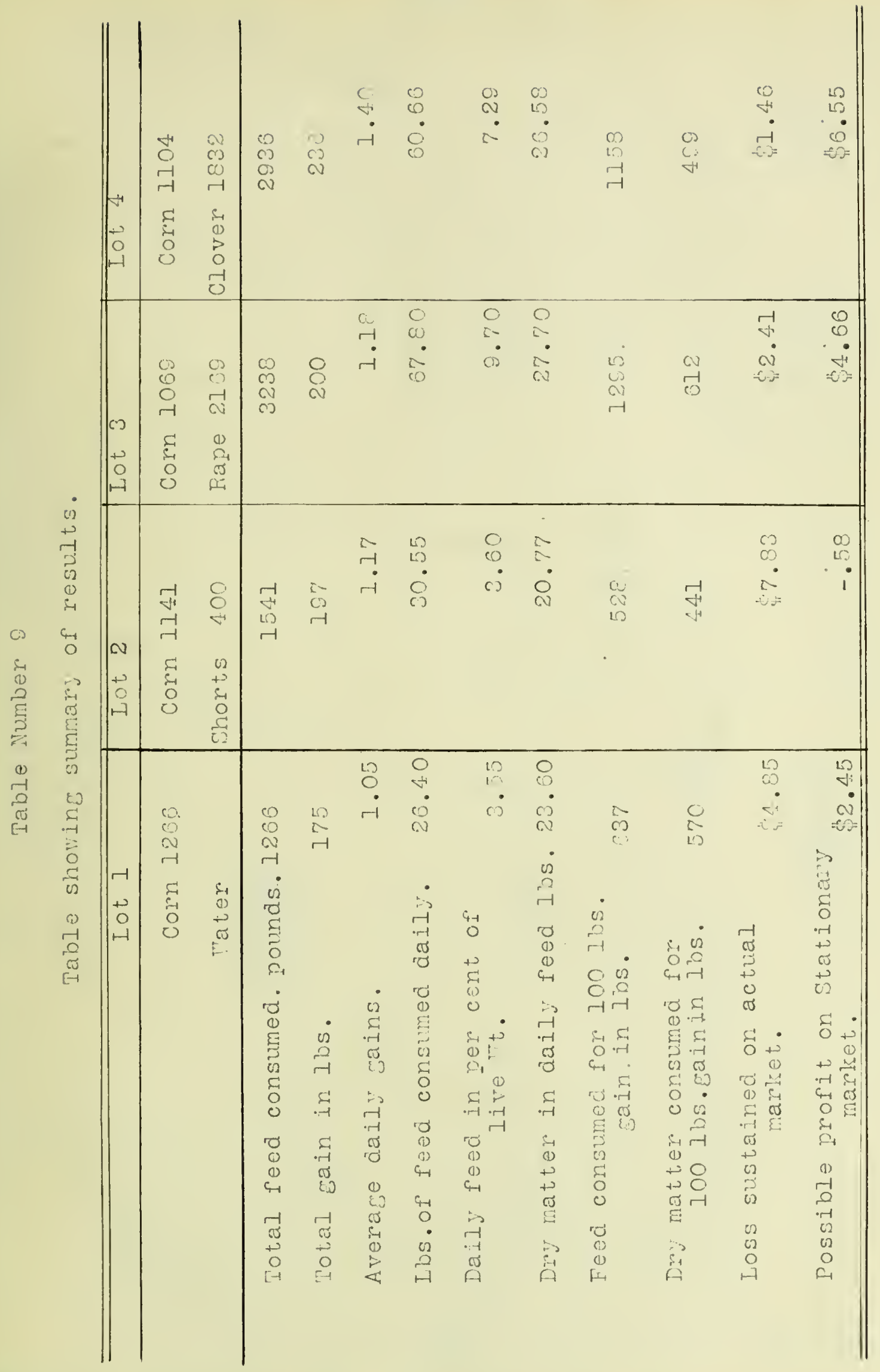



This table shows a sumary of results necessary for comparison. It shows the total feed consumed, total gain in poincs, average daily cain, pounds of feed consumcà daily, dally feed in per cent of live weight, dry matter in daily feed, feec. consumed for 100 pounds gain, loss sustained on actual market, and possible profit on a stationary market. The total feec consumed was createw with the rape lot, this is true because of the amount of bry matter being less, than it is in clover. The clover lot consumed next highest amount of feed. The total feed in both these Iots is probabl: too account of the wa: the amount of rape and clover was determined. In $10 \pm 1$ and 2 the feed ras of more concentrated nature and requireo less to make the cains. The raje and cloves being fed green.

The total gain shows an increase from the corn to corn an clover lot of 31 pounds. Lot 2 and 3 made nearly the same gains which is discussed in the conclusions.

The pounds of feed consumed daily and the daily feed in per cent or live reight var, as cioes the total amount of feed consumed.

The dry matter in the daily feed shows that lot 1 reciovec more din matter per day than did lot 2 mich was fed corn and shorts.

The feed consumed for 100 pounds main was less in the corn arò shorts fed lot than in any other lot and greatest in the corn and rape fec lot. In the corn and rape, and corn and clover lots the amount of feed consumed for 100 pounds gain is pretty hich, but these two lots ate the rape and clover green which is largely composed of water. This and the fact that the estinated amount of rape and clover is high is tive rsason for the large anount of feed.

The ary matter for 100 pounds gain varies as does the amount of feed for 100 pounds gain. 

The Ioss sustained on actua? marlet was createst in lot 2 f'ed. I corn and shorts and least in lot 4 fed corn and clover. The reason these variations in losses is accounted for in the conclusions.

Possible profit or stationary market shows how much profit could have been made had the market price not dropea Iower than that for wicl? the hogs ware bought. This shows the corn and shorts lot to Iose .58 even on a stationary market. The corn and clover lot would have made the best p: oit. The corn and rape second and the corn alone third. 



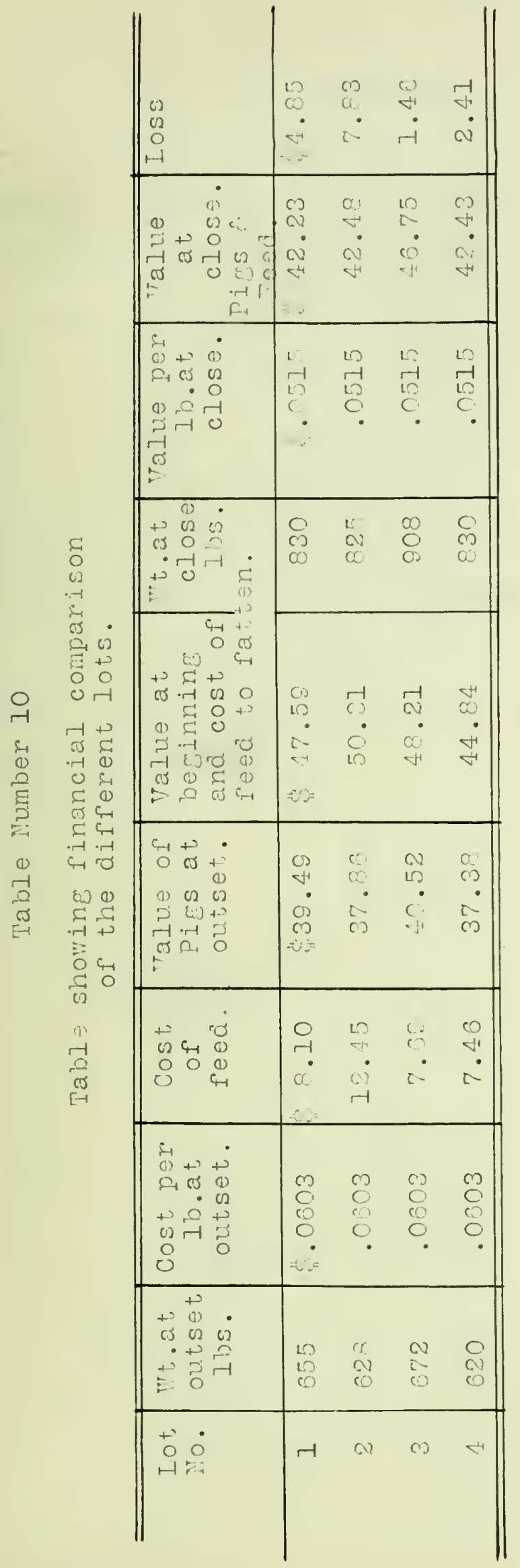





\section{$-10-$}

While experimentally this piece of work was successful the financial side of this experiment was not a success as is shown by the table number 10. The total loss was \$16.65. Tver. oposing condition possible presented itself, which of course could not be prevented.

The pigs in the beginnin cost 6.03 per hundred pounds, and when sold they brought onl" 5.15 per hundrea pounds. The corn that, was fed "as ":orth 45 c per bushel, and the shorts used cost 1.25 per hundred pounds. If the pigs could have been sold for as much as they cost there would have been a nice profit in feecing them. Or as is Eenerally the case, pigs at this age should not have cost as much in proportion as the hog when fattened. Considerins this to be true the profit would have been still larger. While the financial part of of the feeding test was somemat of a railure the data collected is ver" satisfactory. 



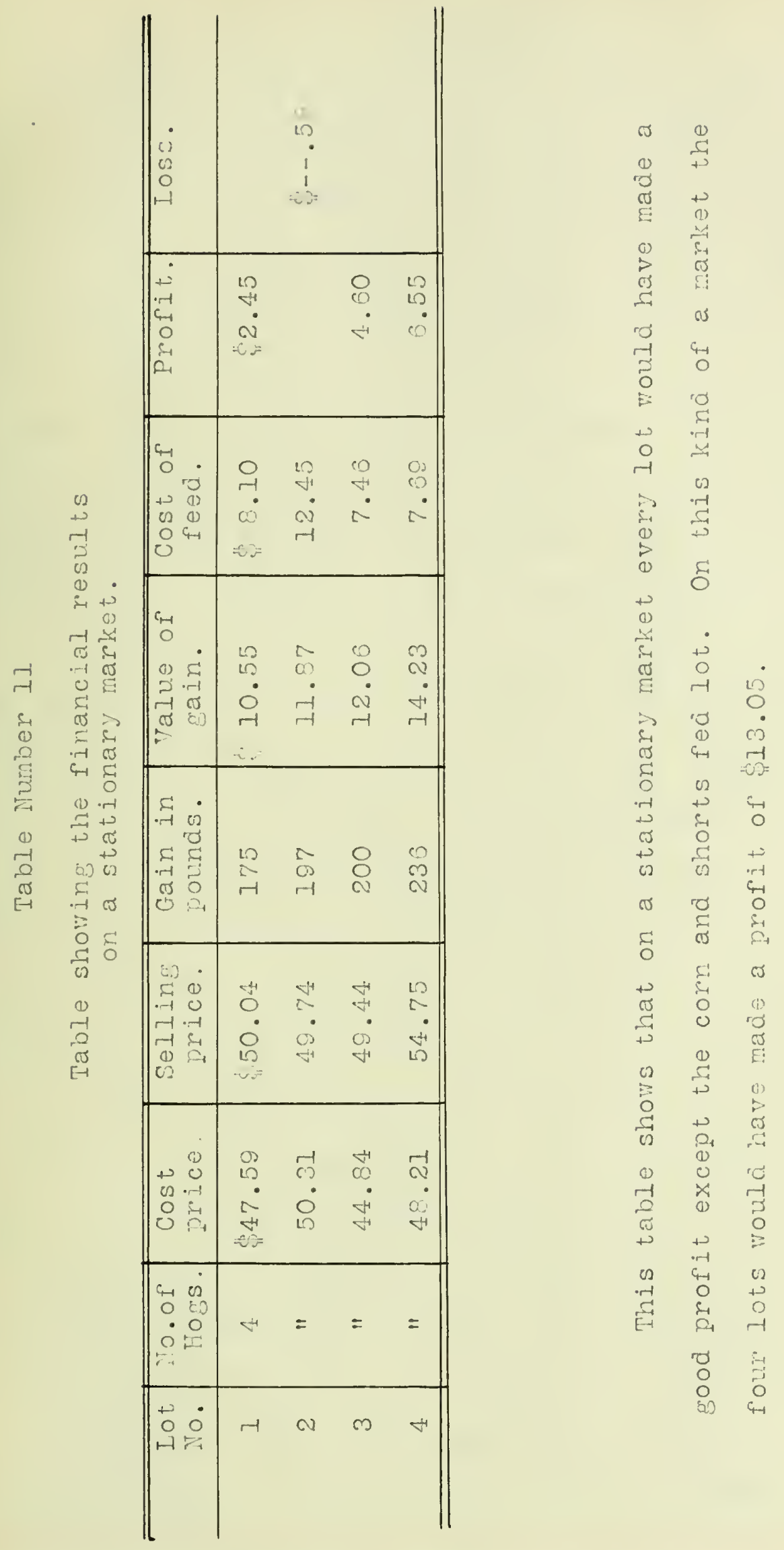





\section{Conclusions.}

Lot number 1 the corn and water fed lot made good gains considoring the conditions; good enough that ordinarily the lot rould have made a good profit. This is the common way of feeding hogs in the com belt and in many cases no doubt a loss of money is the result if an accurate account of all the expense were kept. As has been saic the pigs had been grown princially on a corn ration, this is perhaps a reason that no larger gains were made. In each case whers the feed was changed from what the pigs had been usca to recieving a Ereater increase in gain was recieved. This extra gain no doutbt was largely oue to the kind of feed recieved and the change of feed. The lot fed corn and shorts causec a financial loss, ereater than any other lot. This financial loss was not due to a smaller cain than in lot number I fea on corn, but because it cost so much more to make the extra gain. From these results shorts would not be a practical feed for fattenin hoss at the price paic for the sane, but, it may be practical to feeà them to growing hogs.

Lot number 3 fed on corn and rape made good gains, these gains Were next to those of lot if fed or com and clover. Since rape'is as good a forage croz for hogs as is shom by this experiment it can be profitabl: used for hos pastree. It may be sown at different intervals through the growing season and in this way a continuous succulent pasture may be securec. The rave shovld not be pasturea too close and to prevent coing this it is a good plan to have more than one rape pasture and when one becins to be pasturec pretty short, turn the hogs in the other field until the first one has had a chance to rrow up again. The hogs that were on the rape were in a veri fine 

physical condition, and at no times showed any indications of scouring. The rape apparently is what kept the hogs in such good conoition. Thile the financial side of this lot was not a success, oring to prices paid for the hoss and feed, the data incluaing gains was ver; satisfactory. The rape is lor: in protein content and for the best results when fed to hogs shovld be supplemented by some feed rich in protein.

Lot number 4, the lot fed corn and clover made the largest and cheapest gains. Clover is a crop that can be easily grown in nearly all sections of the corn belt and it certainly furnishes the best pasture for hogs unless alfalfa is better. Clover is twice as rich in nitrogen as is repe. It has $4.4 \%$ protein and rape has $2.3 \%$.

From a standpoint of fertility to the soil, the clover adds nitrogen wich is collected from the air. Excrement from the hoss eating clover will be much higher in nitrogen content than that from hogs eating rape. Rape has very little fertilizing value as it is so largely composed of water. Then pastured the excrement will all be left on the field and the soil will be benefitec from this fact rather than injured. The excrement however from hogs feeding on rape is sure to be lower in nitrogen content than that from those grazing on clover. Since clover has the power of adding nitrogen to the soil thus doine much to keep up its fertilit: there is no doubt but that clover is a more practical pastre than is rape. But in case of a failure of clover rape certainl; is a close second for hoc pasture. 

The Feoding value of Fape as Shown by Experiment at the Wisconsin Station.

F lots or pins of ten each rere used in this test. Lot 1 had rape in comnection with grain. The latter feed was composed. of two parts corn and one part shoits. Iot 2 recieved cratn onl:. The lots were kejt at as nearl: the same weight as possible, as it was thought that this was the best way to obtain the true feeding value of rape. Sesults in the table below show that the lot on rape ate the rap $\Rightarrow$ from one thind acre of land, and requirea 710 pounds less corn and 352 pounds less of shorts thar aid Iot number 2 which recieved no rape. The amount of rape eaten in this case was equivalent to 1062 los. of grain per .32 acre of raje.

An acre of rape unaer these conaitions would result in a saving of 3318 lbs. or grain. 

Fape compareà with grain at Wisconsin.

\begin{tabular}{|c|c|c|c|c|}
\hline Lot. & IDs. of Com. & Los.of Shorts. & Prape.Ins. & Gail. Ios. \\
\hline 1 & $138:$ & 390 & .22 Acres. & 53 \\
\hline $\begin{array}{l}2 \\
=i=2 \\
\text { Iot } 1 .\end{array}$ & $\begin{array}{r}2050 \\
7010 \\
710\end{array}$ & $\begin{array}{l}1042 \\
352\end{array}$ & & 857 \\
\hline
\end{tabular}

Another experiment was conaictec at wisconsin in which clover and rape were compared as a feed for young growing pigs. In this experiment 42 pigs were used, in two lots of 21 each. he pigs averaroa about 100 los in weight. The grains used here vere the same in kind and quantity as for the above lot, composed of one third miàolings and two thircs com meal by weight. The feec was nixed with rater twelve hours before feeding and allowed to soak.

Lot 1 was kept on fresh frowing rape by means of a portable fence. Lot 2 had a range of about 8 acres or clover, afforaing them good pasture at all times.

The rape feo lot thrived best the first part of the test as the rape was in the best orowinés conaition at that time. It later grew hara and "rooä: The clover from the effects of the fall rains ras refreshed and sood pasture was furnished at all times throughout the entire test giving it the advantage at the close. 

Lot I, rape with corn meal and midalings. Table showing cains in two week periods at Wisconsin.

\begin{tabular}{|c|c|c|c|c|}
\hline Weak. & $\begin{array}{c}\text { Co: misaI. } \\
\text { Ios. }\end{array}$ & $\begin{array}{l}\text { Yicolines. } \\
\text { los. }\end{array}$ & $\begin{array}{l}\text { Iotal weights } \\
\text { at boginning } \\
\text { and close. }\end{array}$ & $\begin{array}{l}\text { cotal gain. } \\
\text { los. }\end{array}$ \\
\hline 1. & 350 & 325 & 2130 & 429 \\
\hline 4. & 770 & 385 & & 361 \\
\hline S. & 910 & 485 & & 351 \\
\hline e. & 880 & 490 & & 348 \\
\hline rotal. & 3310 & 15.50 & 3621 & 1402 \\
\hline
\end{tabular}

Iot 2, Clover, corn meal and micalings. Table shoming gains in two $\mathrm{Weel}$

- periods at "isconsin.

\begin{tabular}{|c|c|c|c|c|}
\hline "week. & $\begin{array}{c}\text { Corn neal. } \\
\text { I s. }\end{array}$ & $\begin{array}{c}\text { Uadinges. } \\
\text { Iss. }\end{array}$ & $\begin{array}{l}\text { "rotal weichts } \\
\text { at berimine } \\
\text { and close? }\end{array}$ & $\begin{array}{l}\text { Total gán. } \\
\text { los. }\end{array}$ \\
\hline 1 . & 650 & 325 & 2138 & 347 \\
\hline 1. & 770 & 385 & & 355 \\
\hline ह. & 910 & 455 & & 358 \\
\hline 8. & 880 & 490 & & 375 \\
\hline Total. & 3310 & 1655 & 3573 & 1435 \\
\hline
\end{tabular}



wt. of pigs at becinning. Ibs.

"wt. of pigs at close. los.

Grain eaten one third shorts

two thiràs corn meal. Ios.

Total cain made. los.

Average gain made b" each pis during Exp. Ios.

Average daily gain per pie. Ibs.

Average daily gain per pis for first four weeks. Ibs.

Average dail: gain per pirg for last four meeks. Ios.

\begin{tabular}{c|c}
\hline 10.1 & 10.2 \\
2139 & 2138 \\
3021 & 3573 \\
1969 & 4965 \\
1492 & 1435 \\
7105 & 3833 \\
1.27 & 1.22 \\
1.333 & 1.193 \\
1.183 & 1.247 \\
\hline
\end{tabular}

In a similar experiment to the one above the next year these results were revorsed. When the feeding was begun the rape was small but later wew to be very succulent. While the clover was better when the feeding begun than it was later. Then it will be seen that much depends on the condition of the pasture. 



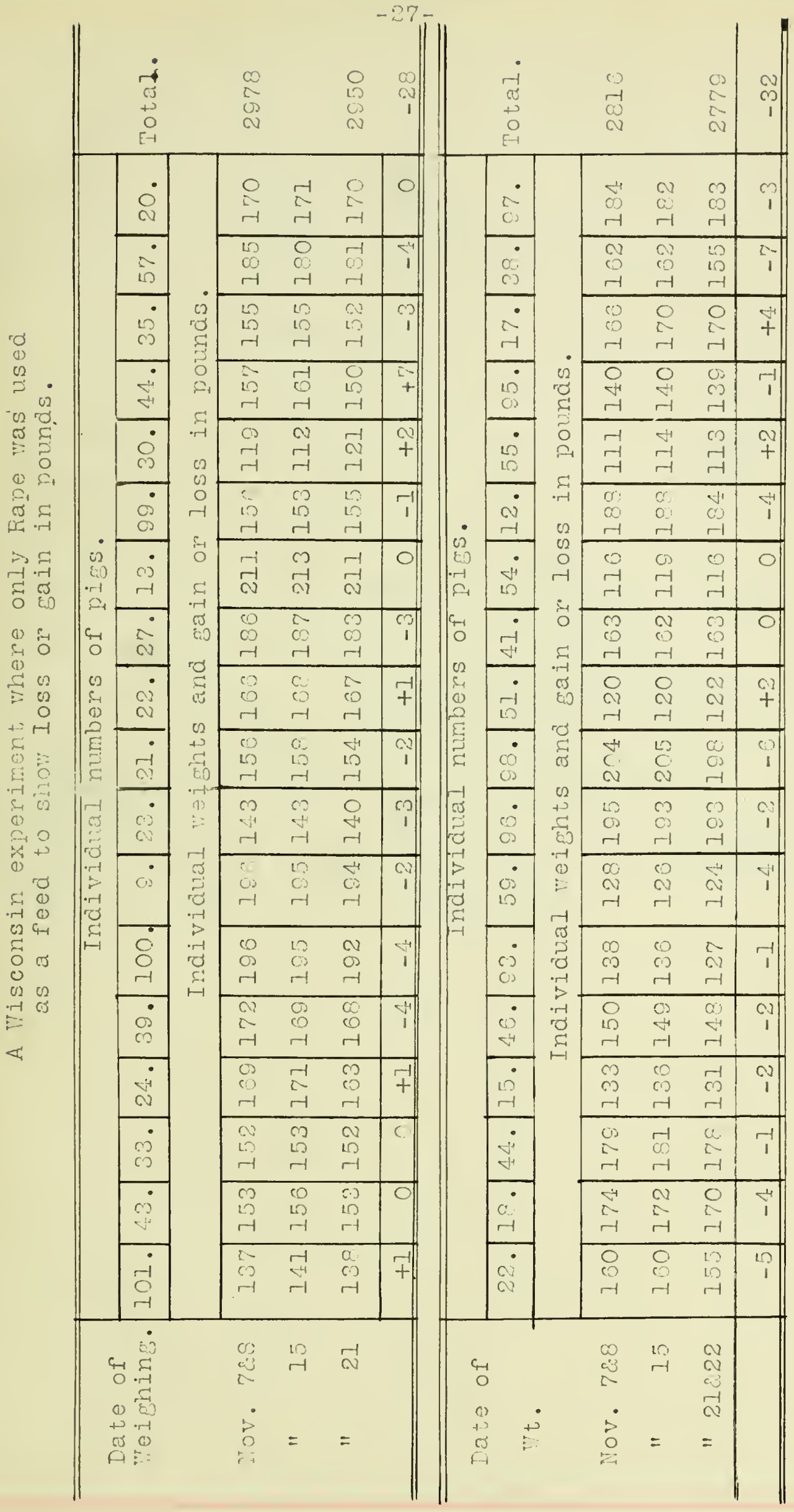



Irotes on Rape Experiment.

The pigs previous to this experiment had been fed on difforent aiets. There were 36 pies in all. Six of them had been fed on an exclusive grain diet for eleven weeks. Iifint had been recieving corn and clover and the other 22 grain and rape. They vere allowed to run in the rape for 3 days and then an initial weight was taken. The pigs were noticed feeding nearly all day, also that tre: ":ere very well contentea never showing signs of hunger. The pies ":ere weighed a week later rov. 15 and the final weights taken "ov. 2: The total loss for the 36 pigs was 60 pounds or one and two third pounds each. The six pigs that had previously been fed on an exclusive grain diet immediately upon beinf turned into rape lost 1 pounds or 3 pounds each. The eight which had a mixed frain diet lost I9 pounds or two and one thirả pounds sach, and the 22 that had recieved grain and rape lost a total of 33 pounds or one and one half pounds each. This shows that rape when not fea in conjunction with other feeds is rather poor in feeain value. 

A Comparison of results of an experiment winch was carried on at Misconsin, similar in nature to the one at Illinois.

\begin{tabular}{|c|c|c|c|c|}
\hline & i'o.of hogs. & Total feed. & Fotal Eain. & Daily cain. \\
\hline Wisconsin. & 21 & 3905 & $14 \mathrm{IE}$ & 1.25 \\
\hline Illinois. & 4. & 3238 㷊 & 200 & 1.18 \\
\hline
\end{tabular}

* The total feed here includes an estinate of the rape eaten an amount of 2169 lbs. The amount of com consumea was 1069 lbs. In the Mis. trial rape is not included in total feed.

In the experiment at "'isconsin, ridalings were fed in conjunction With the com and the pigs allowed to run on rape pasture, at IIl. rape ana corn was fed. The Wisconsin test shows better results from the rape than does the Illinois test. The reason for this aifference is probably âve to the middlinçs which gave them more protein. 

Test There Clover Tas Usea.

\begin{tabular}{c|c|c|c|c}
\hline & io.of hogs. & Totil feed. & Total main. & Daily main. \\
\cline { 2 - 4 } "isconsin. & 21 & 4965 & 1435 & 1.21 \\
Illinois. & 4 & 2936 & 236 & 1.10 \\
\hline \hline
\end{tabular}

The total feed incluaes an estimate of 1832 lbs. for clover consumed. The amount of corn fed was 1104 lbs. In the "is. trial the rape is not counted in total feed.

In the experiment at "isconsin, middlings were fed in conjunction with the corn and pigs allowed to run on clover pasture, at III. corn and clover was fed. The Illinois test shows higher results from the clover and corn than does the "isconsin experiment where midalings ":ere fec with the corn and clover. This difference is perhaps due to the difference in age and size of the pişs at the beginning of the test. The pios in the be jinning of the Tisconsin experiment averaged 100 pounds and those in the Illinois experiment 155 pounds. 



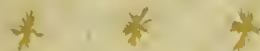

2. $\rightarrow$

$x$

*.

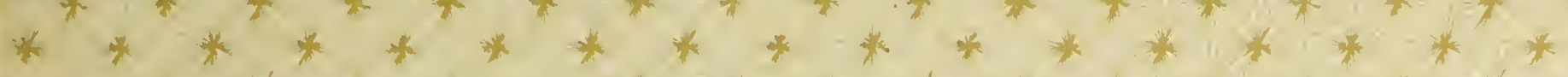

*

th $+\frac{1}{2}$

* $*$ *

$* y=\frac{y}{4}$

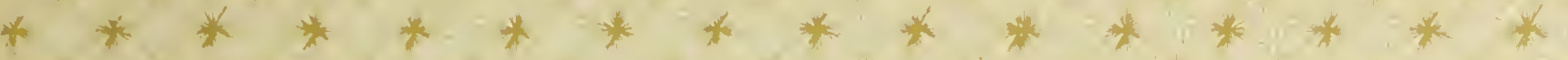

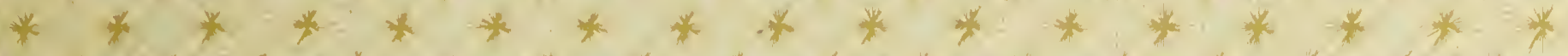

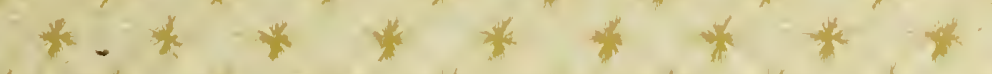

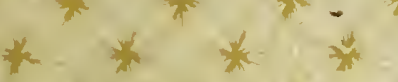
* * $x+y$ * * * * * * $*$

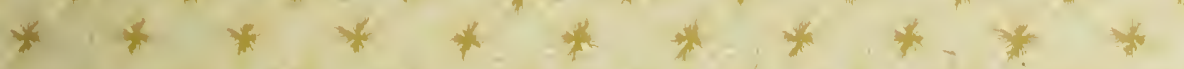

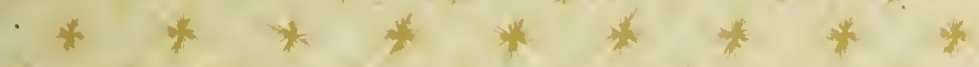

* * * * * * * * * * * * * *

$* * * * * * * * * * 4 *$

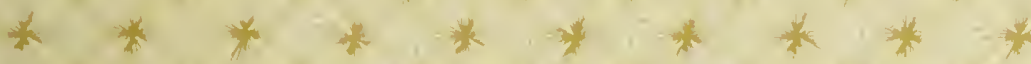

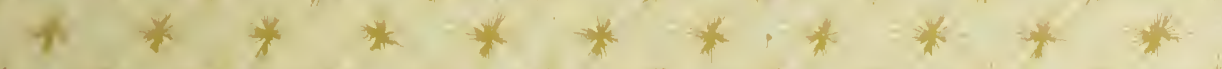

* * * * * * * * * * * * * * * * * * * * * * * *

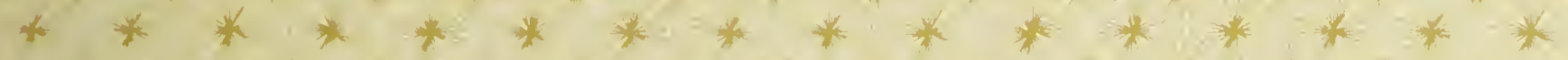

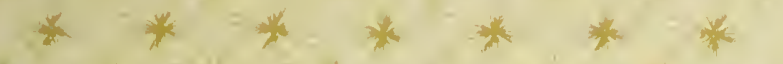

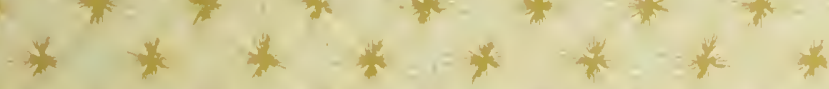

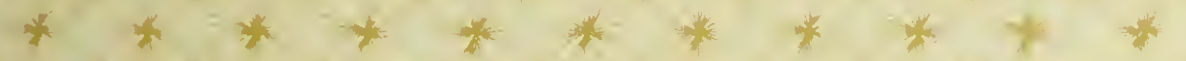

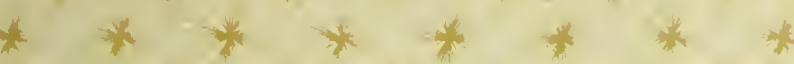
* * * * * * * * * * * * * * * * * *

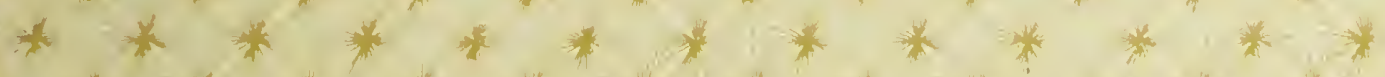

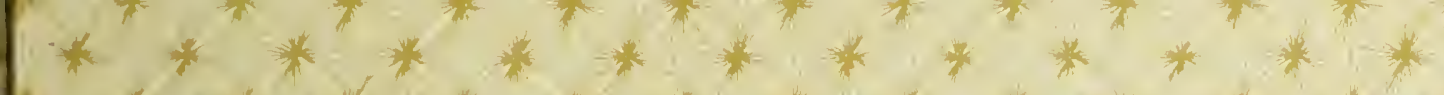

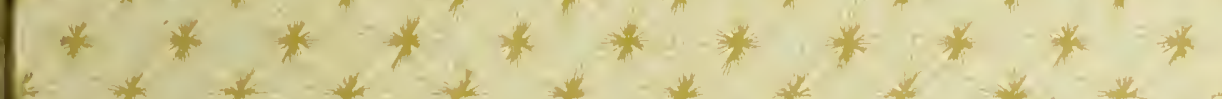

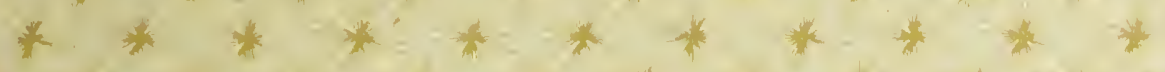

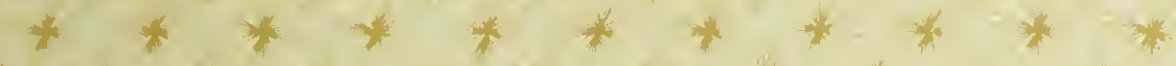

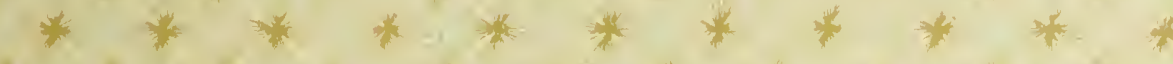

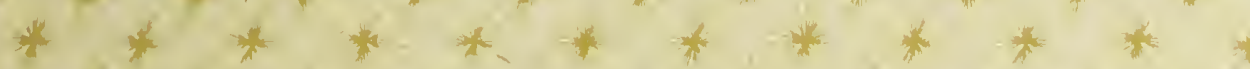

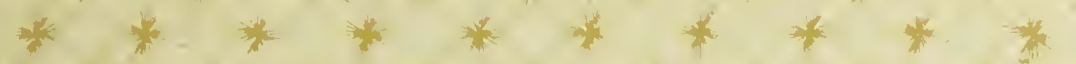

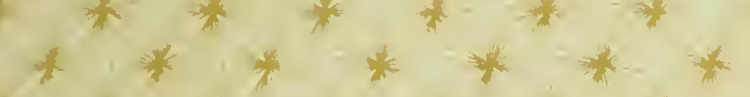
* * * * * * * * * * * * * *

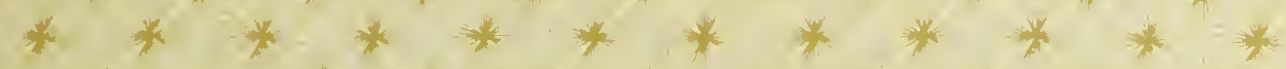

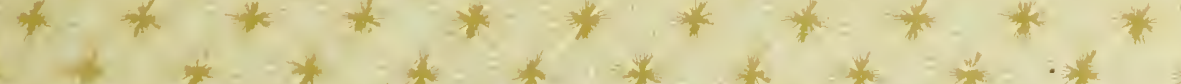

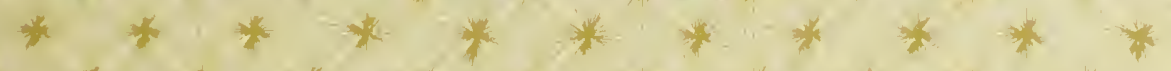

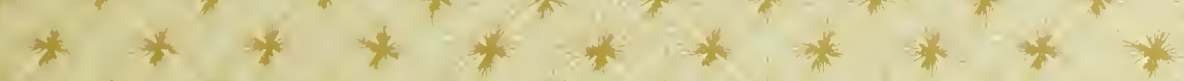

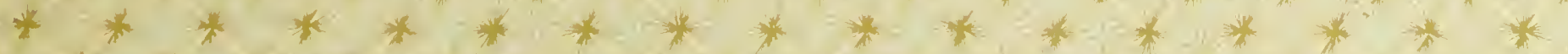




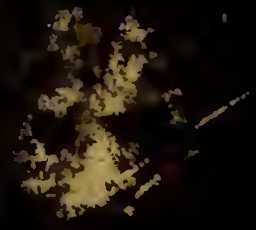

4.4
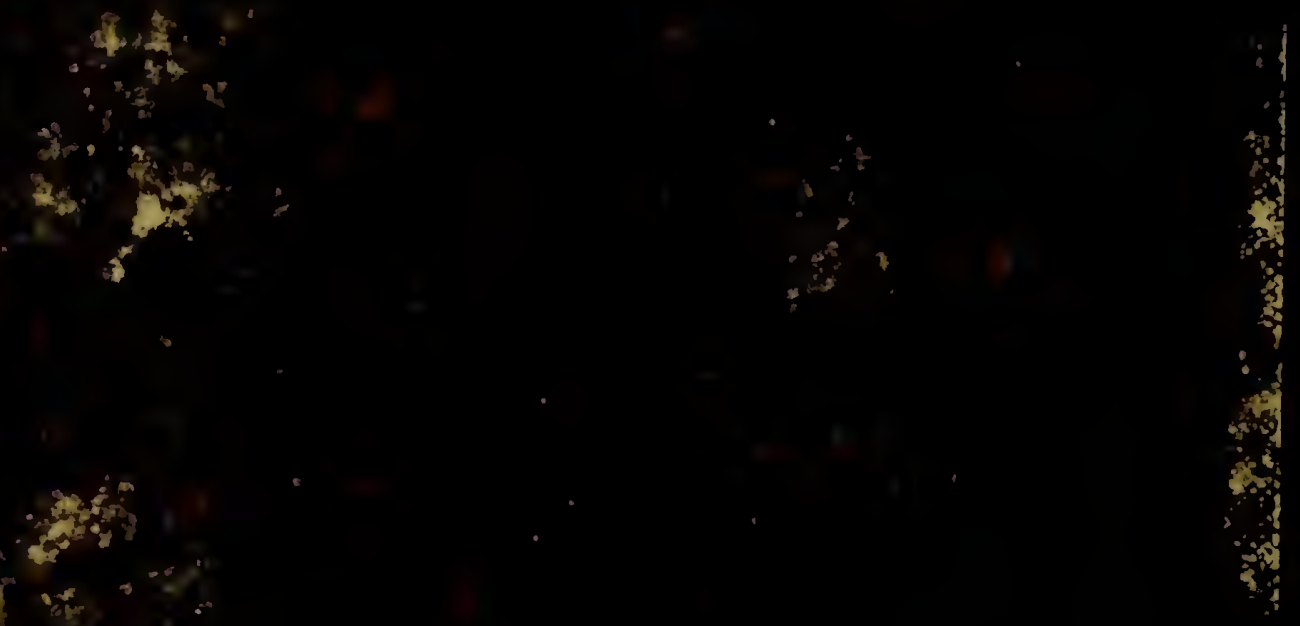

ertit:

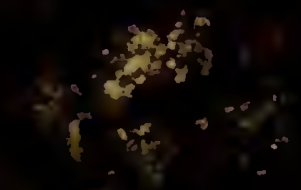

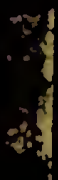

$+\frac{1}{4}$

$3<x^{\circ}=$

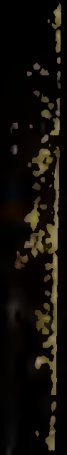

